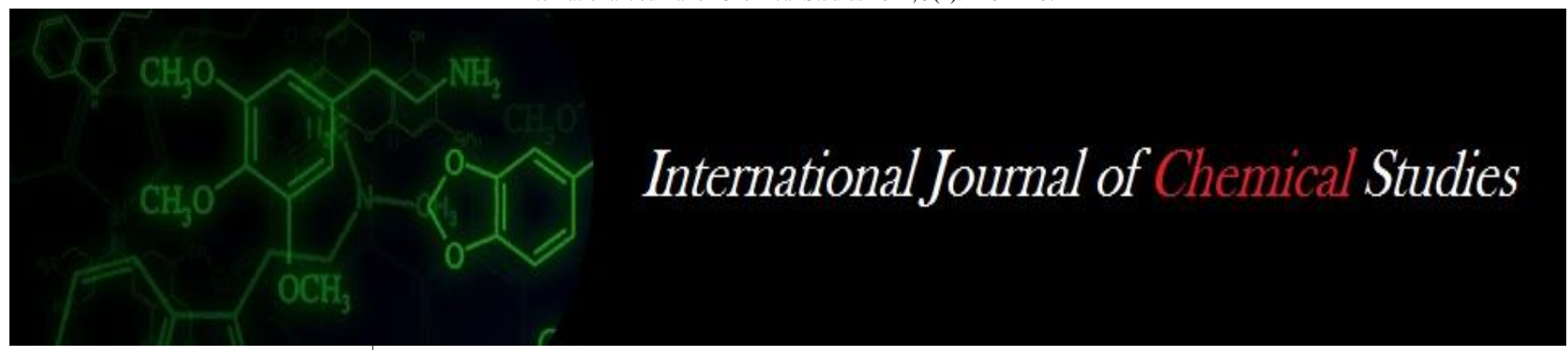

P-ISSN: 2349-8528

E-ISSN: 2321-4902

www.chemijournal.com

IJCS 2021; 9(1): 2164-2167

(C) 2021 IJCS

Received: 21-10-2020

Accepted: 31-12-2020

Uday Kumar Thera

Department of Plant Pathology,

Institute of Agricultural

Sciences, Banaras Hindu

University, Varanasi, Uttar

Pradesh, India

Ashmita Timsina

Department of Plant Pathology,

Institute of Agricultural

Sciences, Banaras Hindu

University, Varanasi, Uttar

Pradesh, India

Naveenkumar Ramaswamy Department of Plant Pathology, Institute of Agricultural

Sciences, Banaras Hindu

University, Varanasi, Uttar

Pradesh, India

Vanama Sowmya

Department of Plant Pathology,

Institute of Agricultural

Sciences, Banaras Hindu

University, Varanasi, Uttar

Pradesh, India

\section{Vineeta Singh}

Professor, Department of Plant

Pathology, Institute of

Agricultural Sciences, Banaras

Hindu University, Varanasi,

Uttar Pradesh, India

Corresponding Author:

Uday Kumar Thera

Department of Plant Pathology,

Institute of Agricultural

Sciences, Banaras Hindu

University, Varanasi, Uttar

Pradesh, India

\section{Survey and incidence of rice sheath blight in major rice growing areas of eastern Uttar Pradesh}

\author{
Uday Kumar Thera, Ashmita Timsina, Naveenkumar Ramaswamy, \\ Vanama Sowmya and Vineeta Singh
}

DOI: https://doi.org/10.22271/chemi.2021.v9.i1ad.11542

\begin{abstract}
Rice is an important food grain and is a staple food for majority of the world's population. Sheath blight $(\mathrm{ShB})$, caused by the soilborne necrotrophic fungal pathogen Rhizoctonia solani Kuhn, is an economically important disease in rice. A purposive disease survey was conducted during Kharif-2019 to assess the occurrence and spread of rice sheath blight disease in five districts of eastern Uttar Pradesh. The percent disease incidence (PDI) ranged from 20 to $80 \%$. Maximum PDI (80) was noticed at paddy field of Sadalpura block (80\%), while minimum (20) was recorded at Narayanpur, and Maudli villages. The maximum severity ( 9 scale) was observed at Sadalpura, Satahara, Naini, Cholapur. The disease was recorded from panicle initiation to grain hardening stage.
\end{abstract}

Keywords: Sheath blight, survey, percent disease incidence, severity

\section{Introduction}

Rice (Oryza sativa L.) being a staple food crop of India, play important role in the food security system. The crop is an important integral part of Indian dietary and staple food of more than $60 \%$ and its cultivation has spread too many parts of the world due to its versatility (Koutu and Rao, 2008; Mishra et al., 2005) ${ }^{[6,9]}$. Both China and India are the largest rice producing countries in world, jointly they account for $51.4 \%$ of the global rice production. In India, nearly 112.9 million tonnes of rice are grown in 43.5 million hectares with the productivity of $2578 \mathrm{~kg} / \mathrm{ha}$. West Bengal is the largest rice producing state in India, and it has 5.82 million ha under rice cultivation, which covers irrigated and rainfed areas with a production of 14.97 million tonnes and productivity of 2.6 tonnes/ha. While in Uttar Pradesh State it is grown in 5.6 million ha, producing 13.28 million tonnes with average productivity of 2 tonnes/ha (2017-18) (www.indiastat.com).

Moreover, the production and productivity of rice is influenced by several abiotic and biotic factors that causes yield losses of up to $45 \%$ (Margani and widadi 2018) ${ }^{[8]}$. Among all the biotic stresses, the fungal diseases in rice are most predominant throughout the world (Asibi et $a l ., 2019)^{[1]}$. The productivity of rice is affected by several pathogens (Margani and widadi $2018)^{[8]}$, of which sheath blight (ShB) disease of rice caused by Rhizoctonia solani Kuhn is one of the destructive pathogen causing disease in rice and considered as world's significant disease, second most predominant to the blast disease (Zheng et al., 2013; Molla et al., 2020) [15]. The ability of pathogen to survive in soil and plant debris enables them to survive in various ways and makes it difficult to fight disease (Kumar et al., 2009) ${ }^{[7]}$. It has become more prevalent in most of the improved varieties currently growing in India (Prakasam et al., 2013) [12]. The spread of disease has extensively increase in terms of both occurrence and intensity over last few decades (Yellareddygari et al., 2014) ${ }^{[14]}$. Currently, it is one of the major production limitations in the states of Eastern Uttar Pradesh, Chhattisgarh, Punjab, Odisha, Uttarakhand, Bihar, West Bengal, Haryana, coastal areas of Andhra Pradesh, Tamil Nadu, Kerala and parts of Karnataka (Prakasam et al., 2013) ${ }^{[12]}$. Study on occurrence of disease in an area can offer an idea on current status of the disease in the various growing zones which is prerequisite to take decision regarding management practices of different diseases (Gangopdhyay and Chakrabarti 1982) ${ }^{[3]}$. 
Therefore, present survey was led in major rice growing regions of Eastern UP to know the incidence and severity of sheath blight in various agro-ecosystems, cropping systems, rice varieties, agronomic practices and management methods in the condition that is a prerequisite to take decision on sustainable disease management practices.

\section{Methods and Materials}

\subsection{Collection of sheath blight samples}

During Kharif 2019, a sample survey was conducted in various parts of Eastern Uttar Pradesh to collect sheath blight infected rice samples for diversity studies in $R$. solani. Hence, a roving survey was carried out in five major rice-growing districts viz., Varanasi, Mirzapur, Prayagraj, Chandauli, and Jaunpur that were selected to collect the infected rice sheath blight samples for the study of variation within $R$. solani AG1 IA (Table 1). From each village randomly 3-5 rice fields were selected when the crop was at tillering to maturity stage. Three plots in each field having an area of one square meter were selected randomly. Data was also collected on stage of the crop, disease severity and incidence in these areas. A sample often consisted of single rice tiller, which either had sheath blight lesion on the sheath/pseudo stem, or the leaves, or both. Symptoms on rice sheaths, leaves and sign (sclerotia) on the disease isolate at each observation during the survey are documented. In addition, information like plant characters and geographical location (longitude/latitude) were compiled.

Disease incidence (DI) was recorded by using the following formula

Disease incidence $=($ Number of infected tillers $/$ Total number of tillers) $\mathrm{x} 100$

\subsection{Isolation and purification of Rhizoctonia solani}

Forty-five isolates were brought to the laboratory and washed under running water to remove dirt particles. Infected plant tissues are cut into small bits $(\sim 0.5 \mathrm{~cm})$, surface sterilized with $1 \%$ sodium hypochlorite solution for 30 seconds and were rinsed three times with sterile distilled water and blotted dry. Hyphal tips of each isolate were transferred to an isolation medium i.e., 2 per cent water agar and incubated at $26 \pm 2{ }^{\circ} \mathrm{C}$. After 2-3 days cultures were examined microscopically for morphological characters typical of $R$. solani. Hyphal tips of each isolate which growing out from the infected plant tissue are sub-cultured on fresh potato dextrose agar (PDA) plates and incubated at $26 \pm 2{ }^{\circ} \mathrm{C}$ for further purification. Following pure cultures of collected isolates were placed at $4^{\circ} \mathrm{C}$ for short term storage. The growth of mycelium in culture plates was documented for every 24 hours.

From each district five to ten rice growing villages and randomly 3-5 rice field having crop at the stage of tillering to maturity are selected. All the isolates were recognized as Rhizoctonia solani based on the right angle branching by microscopic observation. Koch's postulates were proved for all isolates under field conditions during kharif -2019 by using mycelial bit inoculation method.

\subsection{Data analysis}

The relative lesion height $(\mathrm{RLH})(\mathrm{cm})$ was calculated for per tiller, by formula given by Sharma et al. (1990) ${ }^{[13]}$.

$\mathrm{RLH}=$ maximum height at which lesion appear / plant height $\mathrm{x} 100$
The Percentage Disease Index (PDI) was calculated by ranking the RLH on a 0-9 scale of Standard Evaluation System (SES) which gives a measure of disease severity of each tiller.

\section{Disease severity rating scale: (Source: IRRI, 2014) ${ }^{[5]}$ $0=$ No infection \\ $1=$ lesion limited to the lower $20 \%$ of plant height \\ $3=$ lesion limited to the lower $20-30 \%$ of the plant height \\ $5=$ lesion limited to the lower $31-45 \%$ of the plant height \\ $7=$ lesion limited to the lower $46-65 \%$ of the plant height \\ $9=$ lesion more than $65 \%$ of the plant height}

\section{Results and Discussion}

During the year of survey in rice growing regions of Eastern U.P. insect pests and diseases were the main biotic stresses causing significant losses to the rice production. Blast, bacterial leaf blight, brown spot, sheath blight and blast are the major diseases of rice in Eastern UP. Sheath blight is a serious problem in high rainfall areas of eastern U.P. The disease is mostly predominant in areas where the relative humidity is very high (>95\%), the temperature is moderate $\left(28-32^{\circ} \mathrm{C}\right)$ and high nitrogen inputs.

The data presented in the Table. 1 revealed that the per cent disease incidence (PDI) of all isolates ranged from $20 \%$ to $80 \%$ and assembled as four groups such as very high $(>50)$, high $(31-50 \%)$, moderate (20 to $30 \%$ ) and low $(<20 \%)$. Very high incidence noticed at paddy field of sadalpura $(80 \%)$ followed by Cholapur (70\%), Naini (70\%) and Satahara (70), Puarikala (60), SHUATS (college field) (60). High per cent disease incidence recorded at BHU (college field) (50), Chunar (45), Kailahat (40) and jamalpur (40), moderate per cent incidence was observed at Wazidpur (35), Bakiabad (30), Dhara (30), Bichhiya khurd (25), Narayanpur (20), Maudli (20) and none of the locations were recorded as low per cent disease incidence $(<20)$. Among 25 locations, 36\% showed very high incidence $(>50), 28 \%$ location showed high per cent incidence (31-49) and 36 per cent location showed moderate per cent incidence (20-30) (Fig. 1).

Disease severity of collected samples of rice sheath blight ranged from 3 to 9 score (SES Scale). Very high severity (9 scale) was observed at Sadalpura, Satahara, Naini, Cholapur. High disease severity (7 scale) recorded at Kailahat, Chunar, Jamalpur, BHU, Khajuri, Ganja khwaja, Dhanuha, SHUATS, Saidanpur, Kalichabad, and Puarikala. While moderate disease severity (5 scale) noticed at Bichhiya khurd, Dhara, Phaphamau, Dandupur and Meerganj. Low disease severity (3 scale) recorded at Bakiabad, Narayanpur, Maudli, Alinagar, and Wazidpur. Among all the locations $16 \%$ (4) showed $>65 \%$ lesion height (9 score), 44\% (11 locations) recorded $46-65 \%$ lesion height (7 score), $20 \%$ (5) depicted $31-45 \%$ lesion height (5 score), $20 \%$ (5) showed $21-30 \%$ lesion height (3 score).

When the district averages were taken into account, the disease incidence (\%) was found highest in Jaunpur with $48.3 \%$, followed by Varanasi (45\%), Prayagraj (45\%), Chandauli (43\%) and comparatively low in Mirzapur (35\%). These results were in accordance with the findings of Deepak et al., (2018) ${ }^{[2]}$ where they observed highest percent disease incidence of $52.5 \%$ at Nalgonda district and recorded least per cent disease incidence of $20 \%$ in Rangareddy district at Telangana. However, the correlation between crop stages and percent disease incidence and /or disease severity was not detected. Similarly, Parshuram et al., (2017) ${ }^{[11]}$ surveyed in major rice growing areas of Chhattisgarh state for incidence 
and spread of rice sheath blight and reported that Gariyaband district recorded highest mean of incidence $76 \%$ and Durg recorded least mean disease incidence of $30 \%$.

The diversity in incidence may be related to differences in varietal status, planting time, transplanting, soil type, fertilizer dosage and changes in weather conditions. Large-scale cultivation of susceptible varieties as monocrop continuously on the same field could increase the potential for the pathogen to remain in plant debris. The pathogen survives in soil and water in the form of sclerotia which remains viable for up to 3 years (Kumar et al., 2009) ${ }^{[7]}$.

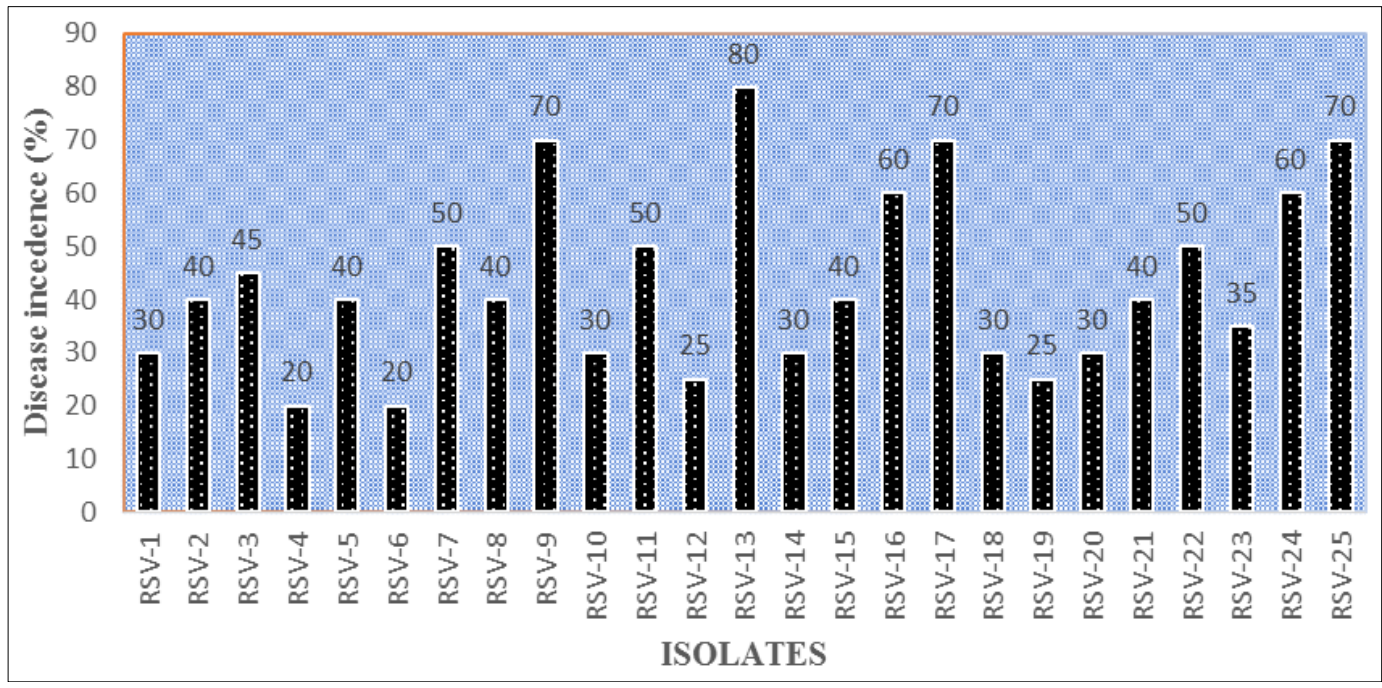

Fig 1: Disease incidence of sheath blight in rice growing regions of eastern Uttar Pradesh during Kharif - 2019

Table 1: Collection of sheath blight disease samples from major rice growing areas of Eastern Uttar Pradesh during Kharif- 2019

\begin{tabular}{|c|c|c|c|c|c|c|c|c|c|}
\hline Isolates & Latitude /Longitude & Districts & Location & Rice variety & Crop stage & $\begin{array}{c}\text { Plant parts } \\
\text { collected }\end{array}$ & DI (\%) & $\begin{array}{c}\text { Severity } \\
(\%)\end{array}$ & $\begin{array}{l}\text { SES } \\
(0-9)\end{array}$ \\
\hline RSV-1 & $25.10^{\prime} 44^{\prime \prime} \mathrm{N} / 82.58^{\prime} 51 " \mathrm{E}$ & Mirzapur & Bakiabad & PNR-381 & Flowering & Leaf & 30 & $21-30$ & 3 \\
\hline RSV-2 & $25.8^{\prime} 55^{\prime \prime} \mathrm{N} / 82.57^{\prime} 22^{\prime \prime} \mathrm{E}$ & Mirzapur & Kailahat & Type-9 & Heading & Sheath \& leaf & 40 & $46-65$ & 7 \\
\hline RSV-3 & $25.7 ' 38^{\prime \prime} \mathrm{N} / 82.54 ' 55^{\prime \prime} \mathrm{E}$ & Mirzapur & Chunar & 1509 & Flowering & Sheath \& leaf & 45 & $46-65$ & 7 \\
\hline RSV-4 & $25.11^{\prime} 52^{\prime \prime} \mathrm{N} / 83.0^{\prime} 49^{\prime \prime} \mathrm{E}$ & Mirzapur & Narayanpur & Narender-118 & Panicle initation & Sheath & 20 & $21-30$ & 3 \\
\hline RSV-5 & $25.7 ' 38^{\prime \prime} \mathrm{N} / 82.54^{\prime} 55^{\prime \prime} \mathrm{E}$ & Mirzapur & Jamalpur & Ganga kaveri & Heading & Sheath & 40 & $46-65$ & 7 \\
\hline RSV-6 & $25.5^{\prime} 9^{\prime \prime} \mathrm{N} / 82.55^{\prime} 2 " \mathrm{E}$ & Varanasi & & & Panicle initatic & Leaf & 20 & $21-30$ & 3 \\
\hline RSV-7 & $25.16^{\prime} 9^{\prime \prime} \mathrm{N} / 82.54^{\prime} 9{ }^{\prime \prime} \mathrm{E}$ & Var & U & uri & e & Sheath & 50 & $46-65$ & 7 \\
\hline RSV-8 & $25.20^{\prime} 19^{\prime \prime} \mathrm{N} / 82.599^{\prime} 28^{\prime \prime} \mathrm{E}$ & asi & Khajuri & Type 21 & ge & Sheath \& leaf & 40 & $46-65$ & 7 \\
\hline RSV-9 & $25.8 ' 33^{\prime \prime} \mathrm{N} / 82.71$ '18"E & asi & Cholapur & Isa Basmathi-1 & & Sheath \& leaf & 70 & $66-100$ & 9 \\
\hline RSV-10 & $25.15^{\prime} 49^{\prime \prime} \mathrm{N} / 83.8^{\prime} 17^{\prime \prime} \mathrm{E}$ & Chat & & & & & 30 & $21-30$ & 3 \\
\hline RSV-11 & $25.15^{\prime} 57^{\prime \prime N} / 83.11^{\prime} 54 " \mathrm{E}$ & $\mathrm{Cb}$ & vii & Co & Panicl & & 50 & $46-65$ & 7 \\
\hline RSV-12 & "N/ 83. & & Bichh & & & & 25 & $31-45$ & 5 \\
\hline RSV-13 & 25.17 & & & & & Sheath \& leaf & 80 & $66-100$ & 9 \\
\hline RSV-14 & 3"E & Cha & $\mathrm{ca}$ & ari & Panicle & Sheath & 30 & $31-45$ & 5 \\
\hline RSV-15 & $25.25{ }^{\prime} 47^{\prime \prime} / 81.81^{\prime} 56^{\prime \prime} \mathrm{E}$ & Prayagraj & & IAUTS dhan & Milky stage & Leaf & 40 & $46-65$ & 7 \\
\hline RSV-16 & $25.42^{\prime} 11^{\prime \prime N} / 81.84 ' 13 " \mathrm{E}$ & Prayagraj & SHUATS & Pant gold & ling & Sheath \& leaf & 60 & $46-65$ & 7 \\
\hline RSV-17 & $25.38^{\prime} 96^{\prime \prime N} / 81.88^{\prime} 79^{\prime \prime} \mathrm{E}$ & & & & $x$ & Leaf & 70 & $66-100$ & 9 \\
\hline RSV-18 & $25.53^{\prime}$ & & Pha & & Panic & & 30 & $31-45$ & 5 \\
\hline RSV-19 & $25.33^{\prime} 96^{\prime \prime N} / 81.82^{\prime} 03^{\prime \prime} \mathrm{E}$ & Prayagraj & Dan & anth-12 & Milky stage & Sheath \& leaf & 25 & $31-45$ & 5 \\
\hline RSV-20 & $25.71^{\prime} 93^{\prime \prime N} / 82.66^{\prime} 32 " \mathrm{E}$ & Jaunpur & Meerganj & Ganga kaveri & Panicle initation & Leaf & 30 & $31-45$ & 5 \\
\hline RSV-21 & $25.71^{\prime} 63^{\prime \prime} \mathrm{N} / 82.62^{\prime} 32^{\prime \prime} \mathrm{E}$ & Jaunpur & idanpur & Manhar & Heading & Sheath & 40 & $46-65$ & 7 \\
\hline RSV-22 & $25.73^{\prime} 98^{\prime \prime} \mathrm{N} / 82.66^{\prime} 05^{\prime \prime} \mathrm{E}$ & & d & & ge & Sheath \& leaf & 50 & $46-65$ & 7 \\
\hline RSV-23 & $25.72^{\prime} 91^{\prime \prime N} / 82.68^{\prime} 211^{\prime E}$ & & & Basmathi-370 & Panicle & & 35 & $21-30$ & 3 \\
\hline RSV-24 & $25.43^{\prime} 92^{\prime \prime N} / 82.92 ' 33^{\prime \prime E}$ & & Puarikala & Sarju-52 & & eath \& le & 60 & $46-65$ & 7 \\
\hline RSV-25 & $25.47^{\prime} 40^{\prime \prime} \mathrm{N} / 83.00^{\prime} 53 " \mathrm{E}$ & Jaunpur & Satahara & Type-3 & Panicle initation & Leaf & 70 & $66-100$ & 9 \\
\hline
\end{tabular}

\section{Conclusion}

Survey on incidence and spread of rice sheath blight in major rice growing regions of Eastern Uttar Pradesh disclosed that disease is a major constrains of the zone. Among the five districts surveyed Jaunpur recorded highest mean of incidence $48.3 \%$ and followed by Varanasi, Prayagraj, Chandauli and comparatively low in Mirzapur (35\%). The prevalence of sheath blight may be caused by the most favourable factors such as high relative humidity, lower temperature and water logging due to continuous rain at these locations during surveying. Large-scale cultivation of susceptible varieties as monocropping continuously in the same field could increase the potential for the pathogens to remain in plant debris. The current study may serve as a harbinger for developing an effective management strategy for the region in an integrated manner for sustainable crop development in the state.

\section{References}

1. Asibi AE, Chai Q, Coulter JA. Rice blast: A disease with implications for global food security. Agronomy 2019;9(8):14. 
2. Deepak Reddy B, Vidya Sagar B, Prakasam V, Sridevi G. Survey on the Sheath Blight disease of Rice in Telangana State, India. Int. J Curr. Microbiol. App. Sci 2018;7(09):3525-3531.

3. Gangopdhyay S, Chakrabarti NK. Sheath blight of rice. Ann. rev. Plant Pathol 1982;61:451-460.

4. India statistics updates, Available 2018. http://www.indiastat.com

5. IRRI. Standard evaluation system for rice: Reference guide. International Rice Research Institute, Los Banos 2014.

6. Koutu GK, Rao SK. Hybrid rice JRH (5) seed production technology. In: National Seed Congress; 91. University of Agricultural Science, Bangalore 2008.

7. Kumar KVK, Reddy MS, Kloepper JW, Lawrence KS, Groth DE, Miller ME. Sheath blight disease of rice (Oryza sativa L.) an overview. Biosci. Biotec. Res. Asia 2009;6:465-480.

8. Margani R, Hadiwiyono H, Widadi S. Utilizing Bacillus to inhibit the growth and infection by sheath blight pathogen, Rhizoctonia solani in rice. IOP Conference Series: Earth and Environmental Science 2018, 142.

9. Mishra B, Rao LVS, Rani NS, Ahmad MI. Inter project linkage-crop improvement review and suggestions for seed research in rice. XX Annual Group Meeting of NSP (crops) Coimbatore 2005.

10. Molla KA, Karmakar S, Molla J, Bajaj P, Rajeev KV, Datta SK et al. Understanding sheath blight resistance in rice: the road behind and the road ahead. Plant Biotec 2019.

11. Parshuram R, Yadav SC, Awadhiya GK, Prasad MS, Prakasam V. Survey and Occurrence of Sheath Blight of Rice in Major Rice Growing Areas of Chhattisgarh. Int. J Pure App. Biosci 2017;5(4):838-845.

12. Prakasam V, Ladhalakshmi D, Laha GS, Krishnaveni D, Sheshu Madhav M, Jyothi B et al. Sheath blight of rice and its management. Technical Bullitin No. 72, Directorate of Rice Research (ICAR), Rajendra Nagar 2013.

13. Sharma NR, Teng PS, Oliver FM. Comparisons of assessment methods for rice sheath blight disease. Philippines. Phytopathology 1990;26:20-24.

14. Yellareddygari SKR, Reddy MS, Kloepper JW, Lawrence KS, Fadamiro H. Rice Sheath Blight: A Review of Disease and Pathogen Management Approaches. J Plant Pathol Microb 2014;5:241.

15. Zheng A, Lin R, Zhang D. The evolution and pathogenic mechanisms of the rice sheath blight pathogen. Nature communications 2013;4.1424.10.1038/ ncomms 2427. 